
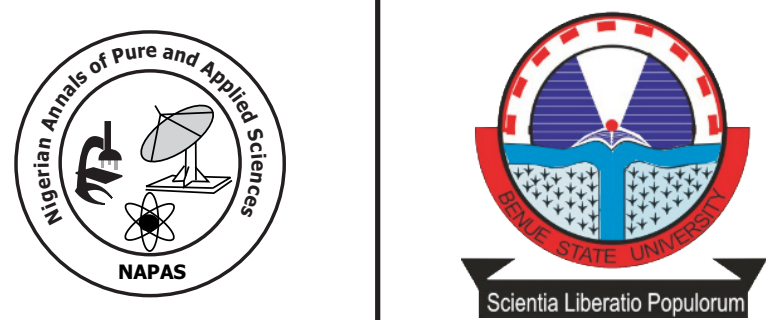

\title{
Concentration of Heavy Metals in Soil around Dumpsites in Jimeta and Ngurore, Adamawa State, Nigeria
}

\begin{abstract}
*Corresponding author: dsakiyo1@gmail.com

Rapid urbanization and industrialization in developing countries have been associated with production and deposition of hazardous wastes in the soil environments. Heavy metals are major components of these wastes and have been implicated in several metal-related diseases and food poisoning in man. This study examined the concentration of Iron $(\mathrm{Fe})$, Lead $(\mathrm{Pb})$, Copper $(\mathrm{Cu})$, Chromium $(\mathrm{Cr})$, and Cadmium $(\mathrm{Cd})$ heavy metals in soil near dumpsites of Jimeta and Ngurore, Yola North Local Government Areas (LGAs), Adamawa State. Soil samples from $0-20 \mathrm{~cm}$ layer depth were collected in triplicates and analyzed using atomic absorption spectrophotometer (AAS). Results reveal that $\mathrm{Fe}, \mathrm{Pb}, \mathrm{Cu}$ and Chromium were detected, while Cadmium was found to be below the limit of detection. The mean concentration of the exchangeable cation in $\mathrm{mg} / \mathrm{kg}$ in soil at Jimeta sites were: $\mathrm{Fe}(31.4 \mathrm{mg} / \mathrm{kg})>\mathrm{Pb}(0.92 \mathrm{mg} / \mathrm{kg})>\mathrm{Cu}(0.34 \mathrm{mg} / \mathrm{kg})>\mathrm{Cr}(0.11 \mathrm{mg} / \mathrm{kg})>\mathrm{Cd}$ (below limit of detection), while the mean concentration of the heavy metals in soil at Ngurore sites were: $\mathrm{Fe}(32 \mathrm{mg} / \mathrm{kg})>\mathrm{Pb}$ $(0.83 \mathrm{mg} / \mathrm{kg})>\mathrm{Cu}(0.28 \mathrm{mg} / \mathrm{kg})>\mathrm{Cr}(0.07 \mathrm{mg} / \mathrm{kg})>\mathrm{Cd}$ (below limit of detection), respectively. Iron (Fe) was the most abundant element in both sites, followed by $\mathrm{Pb}$. Heavy metal concentrations in soil followed the order of $\mathrm{Fe}>\mathrm{Pb}>\mathrm{Cu}>\mathrm{Cr}>\mathrm{Cd}$, respectively. The paired T-test analyses for concentration of $\mathrm{Cr}, \mathrm{Fe}$, and $\mathrm{Pb}$ in soil near the two dumpsites show that there were statistically significant differences in the concentration levels of $\mathrm{Cr}$, $\mathrm{Fe}$, and $\mathrm{Pb}$, while $\mathrm{Cu}$ showed no statistically significant difference between the two dumpsites. However, all the metals detected were below the permissible limit of WHO international standard with the exception of $\mathrm{Pb}$ whose concentration was above maximum permissible concentration (MPC). Persistent heavy metals accumulation in soils near these dumpsites may lead to increase uptake by vegetables grown near thedumpsites and this may pose a threat to its quality and safety and ultimately human health. The need to replace open dumpsites with well-designed landfills is advised.
\end{abstract}

Keywords: Heavy metals, Soil contamination, Dumpsite, Solid waste. Jimeta-Ngurore. 


\section{Introduction}

Heavy metals are non-biodegradable and their persistent contamination of the environment is a great source of concern. The use of dumpsite soils as organic manure is widespread, this practice have been known to improve soil properties such as organic matter, nutrients, porosity, aggregate stability, bulk density and water retention, and as a result, increase plant productivity (Oluyemi et al., 2008; Olarinoye et al., 2010). However, it is a known fact that some of the waste products contain hazardous metals such as $\mathrm{Cr}, \mathrm{Pb}, \mathrm{Cd}, \mathrm{Fe}$, and $\mathrm{Cu}$, which perturb the distribution and concentration of these metals in the environment. Recent studies have also revealed that the waste dumpsite can transfer significant levels of these toxic and persistent metals into the soil environment (Adelekan and Alawode, 2011; Abdallahet al., 2011). The presence of heavy metals such as cadmium $(\mathrm{Cd})$, lead $(\mathrm{Pb})$ and chromium $(\mathrm{Cr})$ in agricultural soils are mostly influenced by anthropogenic activity (Fytianoset al., 2001). Elevated concentrations of these metals inhibit plant growth parameters; including respiration, photosynthesis, water and nutrient uptake, resulting in reduction of plant production (Ali et al., 2015). Elevated concentration of toxic elements in soil are result of different anthropogenic activities, environmental pollution from industrial emission, utilization of waste water for irrigation, certain agricultural practices, application of nitrogen and phosphorous fertilizers, atmospheric depositions during transportation and marketing, etc. (Sharma et al., 2006; Nikolićet al., 2014). The rapid urbanization and industrialization have caused elevation of heavy metals content in urban environments in different developing countries (Radwan and Salama 2006; Sharma et al., 2008a; Kiende et al., 2012). Rapid and unorganized urban and industrial developments have contributed to the elevated levels of heavy metals in the urban environment of developing countries such as Egypt (Radwan and Salama, 2006), Iran (Maleki and Zarasvand, 2008), China (Wong et al., 2003) and India (Marshall, 2004; Sharma et al., 2008b).

Emissions of heavy metals from industries and vehicles may be deposited on soil surfaces increasing soil contamination (Al Jassiret al., 2005). Soils may become contaminated by the accumulation of heavy metals and metalloids through emissions from the rapidly expanding industrial areas, mine tailings, disposal of high metal wastes, leaded gasoline and paints, land application of fertilizers, animal manures, sewage sludge, pesticides, wastewater irrigation, coal combustion residues, spillage of petrochemicals, and atmospheric deposition (Khan et al.,, 2008). Heavy metals constitute an ill-defined group of inorganic chemical hazards, and those most commonly found at contaminated sites are: Lead $(\mathrm{Pb})$, Chromium $(\mathrm{Cr})$, Arsenic (As), Zinc ( $\mathrm{Zn})$, Cadmium (Cd), Copper (Cu), Mercury ( $\mathrm{Hg})$, and Nickel (Ni). Soils are the major sinks for heavy metals released into the environment by aforementioned anthropogenic activities and unlike organic contaminants which are oxidized to carbon (iv) oxide by microbial action, most metals do not undergo microbial or chemical degradation, and their total concentration in soils persists for a long time after their introduction (Adriano, 2003). The presence of toxic metals in soil can severely inhibit the biodegradation of organic contaminants. Heavy metal contamination of soil may pose risks and hazards to humans and the ecosystem through: direct ingestion or contact with contaminated soil, the food chain (soil-plant-human or soil-plantanimal-human), drinking of contaminated ground water, reduction in food quality (safety and marketability) through phytotoxicity, reduction in land usability for agricultural production causing food insecurity, and land tenure problems (McLaughlin, 2000).

The adequate protection and restoration of soil ecosystems contaminated by heavy metals require their characterization and remediation. Contemporary legislation respecting environmental protection and public health, at both national and international levels, are based on data that characterize chemical properties of environmental phenomena, especially those that reside in our food chain (Kabata and Pendias, 2001). While soil characterization would provide an insight into heavy metal speciation and bioavailability, attempt at remediation of heavy metal contaminated soils would entail knowledge of the source of contamination, basic chemistry, and environmental and associated health effects (risks) of these heavy metals. Risk assessment is an effective scientific tool which enables decision makers to manage sites so contaminated in a costeffective manner while preserving public and ecosystem health (Zhao and Kaluarachchi, 2002).

Immobilization, soil washing, and phytoremediation techniques are frequently listed among the best demonstrated available technologies (BDATs) for remediation of heavy metal-contaminated sites. In spite of their costeffectiveness and environment friendliness, field applications of these technologies have only been reported in developed countries. In most developing countries, these are yet to become commercially available technologies possibly due 
to the inadequate awareness of their inherent advantages and principles of operation. With greater awareness by the governments and the public of the implications of contaminated soils on human and animal health, there has been increasing interest amongst the scientific community in the development of technologies to remediate contaminated sites. In developing countries with great population density and scarce funds available for environmental restoration, low-cost and ecologically sustainable remedial options are required to restore contaminated lands so as to reduce the associated risks, make the land resource available for agricultural production, enhance food security, and scale down land tenure problems (Zhao and Kaluarachchi, 2002).

Permissible levels of heavy metal content in soilwere compared with Maximum permissible concentrations (MPC) values recommended by WHO.

\begin{tabular}{llllll}
\hline Heavy metal & $\mathrm{Cd}$ & $\mathrm{Pb}$ & $\mathrm{Cr}$ & $\mathrm{Fe}$ & $\mathrm{Cu}$ \\
Permissible levels in soil set up by WHO & 0.2 & 0.3 & 2.3 & 65 & 0.3 \\
\hline
\end{tabular}

There is lack of studies which determine the pollution level created due to the dumpsite at any particular location in most of the developing countries. Therefore, this study was designed with the aim of assessing the pollution level of the dumpsite due to the application of solid waste, through the determination of selected physicochemical parameters in the soil of the dumpsite and its surrounding areas located at Jimeta and Ngurore with potential ecological and public health risk. It will further provide basis for further actions in regards to existing environmental challenges.

\section{Materials and methods \\ Description of the Study Area}

The study was conducted in Jimeta and Ngurore, Yola-North LGA, respectively, Adamawa Central, North-Eastern Nigeria. The area lies between latitude $9^{\circ} 15^{\prime} \mathrm{N} 12^{\circ} 25^{\prime} \mathrm{E}$ and longitude $9^{\circ} 20^{\prime} \mathrm{N} 12^{\circ} 30^{\prime} \mathrm{E}$, covering a total area of 1,213.30 sq. $\mathrm{km}^{2}$ (Figure 1 and Figure 2). The coordinates for the respective dumpsites is shown in table 1 . The area has a tropical climate, marked by dry and rainy seasons. The rainy season commences around May and ends in the middle or late October. The rainfall is characterized by a single maximum with a mean total rainfall of $1,113.3 \mathrm{~mm}$. The dry season starts in late October and ends in late April (Adebayo and Tukur, 1999). Maximum temperatures in Yola can reach $40^{\circ} \mathrm{C}$, around April, while minimum temperature could be as low as $18.30{ }^{\circ} \mathrm{C}$ between December and early January, which marks the harmattan season characterized by northeast westerly winds that blows across the Sahara desert carrying with it dust particles. Relative humidity in the area is about $26 \%$ in the months of January, while February is the lowest; with high relative humidity values of $58,69,79,79,77$ and 66 , respectively which could be recorded during the months of May to October, particularly during the months of July and August as the peak, with about $80 \%$ relative humidity (Adebayo and Tukur, 1999). Most inhabitants in the area are civil servants, traders, fishermen, farmers and cattle rearing.

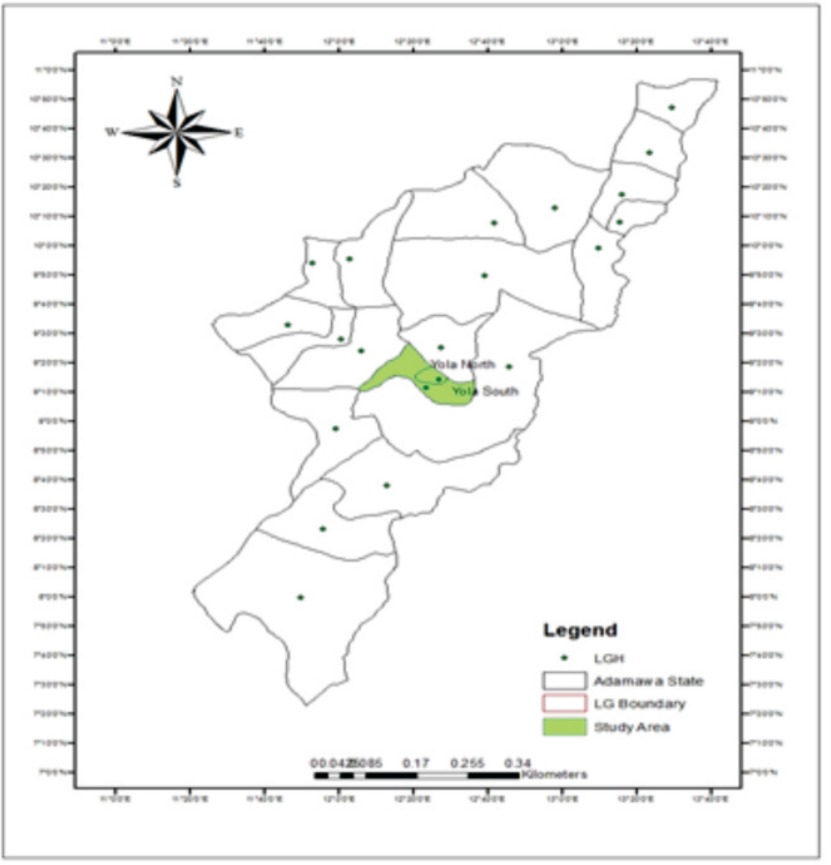

Fig. 1: Map of Adamawa showing study area. 


\section{Collection of samples}

Soil samples were collected from six (6) sites each within the dumpsite vicinity of Jimeta and Ngurore areas. One (1) soil sample was collected from six (6) sites making a total of twelve (12) soil samples, six for each study area mentioned. Soil samples were collected at depth between $0-20 \mathrm{~cm}$, to serve as future surveillance points, coordinates of these points were recorded using global positioning system (Garmin, GPS72H).

Table 1: Sampling coordinates at the study area

\begin{tabular}{|c|c|c|c|c|c|}
\hline $\mathbf{S} / \mathbf{N}$ & LGA & Dumpsite & Ward & Latitude (N) & Longitude(E) \\
\hline \multirow[t]{6}{*}{1} & Yola-North & Jimeta & Dobeli & $9.287804^{0} \mathrm{~N}$ & $12.458260^{\circ} \mathrm{E}$ \\
\hline & & & & $9.287644^{0} \mathrm{~N}$ & $12.458201^{0} \mathrm{E}$ \\
\hline & & & & $9.288050^{\circ} \mathrm{N}$ & $12.457797^{0} \mathrm{E}$ \\
\hline & & & & $9.287317^{\circ} \mathrm{N}$ & $12.457571^{0} \mathrm{E}$ \\
\hline & & & & $9.287517^{0} \mathrm{~N}$ & $12.456770^{\circ} \mathrm{E}$ \\
\hline & & & & $9.287451^{\circ} \mathrm{N}$ & $12.455511^{0} \mathrm{E}$ \\
\hline \multirow[t]{6}{*}{2} & Yola-South & Ngurore & Ngurore & $9.287485^{\circ} \mathrm{N}$ & $12.233566^{0} \mathrm{E}$ \\
\hline & & & & $9.287175^{\circ} \mathrm{N}$ & $12.233432^{0} \mathrm{E}$ \\
\hline & & & & $9.287721^{\circ} \mathrm{N}$ & $12.233568^{0} \mathrm{E}$ \\
\hline & & & & $9.287335^{\circ} \mathrm{N}$ & $12.233653^{0} \mathrm{E}$ \\
\hline & & & & $9.287359^{\circ} \mathrm{N}$ & $12.233500^{\circ} \mathrm{E}$ \\
\hline & & & & $9.286963^{\circ} \mathrm{N}$ & $12.233211^{0} \mathrm{E}$ \\
\hline
\end{tabular}

Source: Field Survey 2018

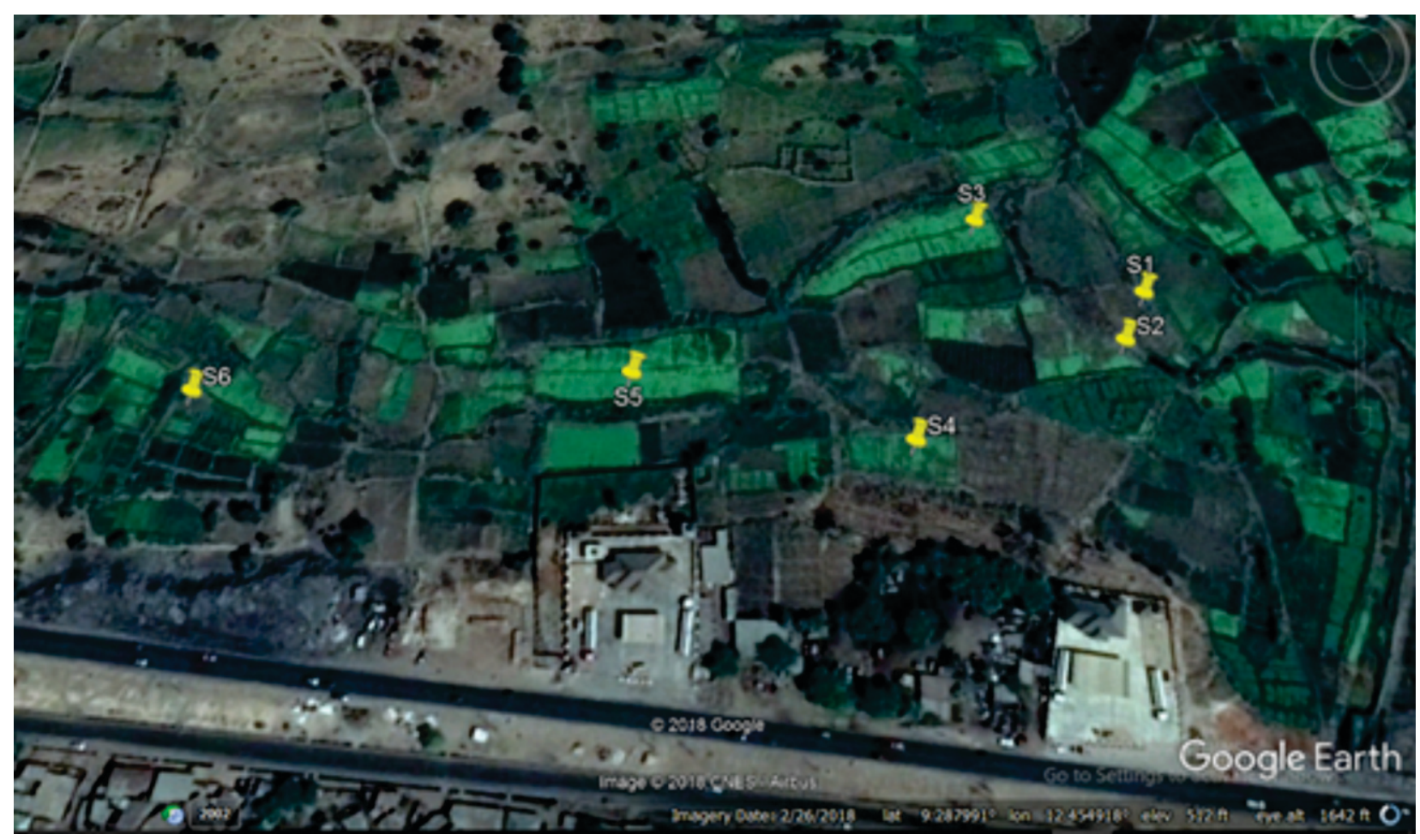

Fig. 2: Soil sampling locations near Jimeta city solid waste dumpsite, 2018.

Soil samples were dried at room temperature and then kept in an oven at $65^{\circ} \mathrm{C}$ for $24 \mathrm{hrs}$ before being grinded using an electric grinder. The soil samples were further sieved to $1 \mathrm{~mm}$ size. About $6.00 \mathrm{~g}$ of the powder from each soil sample was mixed with $1.35 \mathrm{~g}$ of starch binder and placed into a polished lapped thrust piece with smooth surface and fixed into hydraulic press machine. The pellets in pressed tablets were obtained by applying an average pressure of 20 bars. (FAO/WHO 2001; Chailapakulet al., 2007; Wuana and Okieimen, 2011).Determination of the heavy metals such as $\mathrm{Cu}, \mathrm{Cr}, \mathrm{Fe}, \mathrm{Cd}$ and $\mathrm{Pb}$ in the filtrate of soil was achieved by Atomic Absorption Spectrophotometer (Air Acetylene flame intergraded mode, Buck 210VGP) after wet digestion with a mixture of $\mathrm{HCl}$ and $\mathrm{HNO}_{3}$ in the Laboratory. The $\mathrm{pH}$ value was also determined 
using glass electrode method with a standard calibrated pH meter (Gupta et al., 2008; Khan et al., 2008).

\section{Statistical Analysis}

SPSS Version 22.0 was used for analysis. The data obtained were subjected to descriptive and inferential statistics. Descriptive statistics mainly mean and standard deviation was used to describe the concentration levels of heavy metals in soil near Jimeta and Ngurore dumpsites. The recorded data was also subjected to Paired T-Test to assess the difference in heavy metals concentration in soil near the two dumpsites. The level of significance was set at P 0.05 .

\section{Results}

The results pertaining Cadmium (Cd) was omitted because $\mathrm{Cd}$ concentration was below the instrumental detection limit in all the soil samples. The maximum permissible concentrations (MPC) of $\mathrm{Fe}, \mathrm{Cu}, \mathrm{Cr}, \mathrm{Pb}$ and $\mathrm{Cd}$ in dry soil vary in comparison to standard values set up by (FAO/WHO, 2007). Levels of heavy metals Concentrations in soil near Jimeta dumpsite show that in Site 1: Fe with $(27.54 \mathrm{mg} / \mathrm{kg})$ recorded the highest metal concentration, followed by $\mathrm{Cu}$ $(0.44 \mathrm{mg} / \mathrm{kg}), \mathrm{Pb}(0.28 \mathrm{mg} / \mathrm{kg}), \mathrm{Cr}(0.1 \mathrm{mg} / \mathrm{kg})$ while $\mathrm{Cd}$ was not detected in the sample. In site 2 : $\mathrm{Fe}$ with $(35.68 \mathrm{mg} / \mathrm{kg})$ recorded the highest metal concentration, Followed by $\mathrm{Pb}(1.19 \mathrm{mg} / \mathrm{kg}), \mathrm{Cu}$ $(0.13 \mathrm{mg} / \mathrm{kg}) . \mathrm{Cr}(0.1 \mathrm{mg} / \mathrm{kg}), \mathrm{Cd}(\mathrm{ND})$ was beyond the detection limit. Site 3: Fe $(33.39 \mathrm{mg} / \mathrm{kg})$ indicated the highest metal concentration in soil, followed by $\mathrm{Pb}(1.35 \mathrm{mg} / \mathrm{kg})$ and $\mathrm{Cu}(0.58 \mathrm{mg} / \mathrm{kg})$, $\mathrm{Cr}(0.01 \mathrm{mg} / \mathrm{kg})$ and $\mathrm{Cd}$ was beyond the limit of detection. Site $4: \mathrm{Fe}(24.34 \mathrm{mg} / \mathrm{kg})$ recorded the highest metal concentration in soil, followed by $\mathrm{Cu}(0.32 \mathrm{mg} / \mathrm{kg}), \mathrm{Pb}(0.23 \mathrm{mg} / \mathrm{kg}), \mathrm{Cr}(0.2 \mathrm{mg} / \mathrm{kg})$, and $\mathrm{Cd}$ was not detected (ND). Site 5 : Fe with
$(36.22 \mathrm{mg} / \mathrm{kg})$ showed the highest metal concentration in soil, followed by $\mathrm{Pb}(1.2 \mathrm{mg} / \mathrm{kg})$, $\mathrm{Cr}(0.2 \mathrm{mg} / \mathrm{kg}), \mathrm{Pb}(0.14 \mathrm{mg} / \mathrm{kg})$ and the least was $\mathrm{Cd}$ (ND). Site 6: Indicated that $\mathrm{Fe}$ with $(31.28 \mathrm{mg} / \mathrm{kg})$ recorded the highest concentration of metals, followed by $\mathrm{Pb}(1.29 \mathrm{mg} / \mathrm{kg}), \mathrm{Cu}$ $(0.44 \mathrm{mg} / \mathrm{kg}), \mathrm{Cr}(0.02 \mathrm{mg} / \mathrm{kg})$, and $\mathrm{Cd}$ was beyond the detection of limit (Table 2 ).

Heavy metals Concentrations in soil at Ngurrore dumpsite indicated that in Site 1: Fe with $(34.484 \mathrm{mg} / \mathrm{kg})$ recorded the highest metal concentration, followed by $\mathrm{Cu}(0.31 \mathrm{mg} / \mathrm{kg}), \mathrm{Pb}$ $(0.22 \mathrm{mg} / \mathrm{kg}), \mathrm{Cr}(0.1 \mathrm{mg} / \mathrm{kg})$ and $\mathrm{Cd}$ was beyond the detection limit. In site 2 : Fe with $(31.23 \mathrm{mg} / \mathrm{kg})$ recorded the highest metal concentration, Followed by $\mathrm{Pb}(1.04 \mathrm{mg} / \mathrm{kg}), \mathrm{Cu}(0.283 \mathrm{mg} / \mathrm{kg})$. $\mathrm{Cr}(0.1 \mathrm{mg} / \mathrm{kg})$ and $\mathrm{Cd}(\mathrm{ND})$ were not detected. Site 3: Fe $(29.71 \mathrm{mg} / \mathrm{kg})$ indicated the highest metal concentration in soil, followed by $\mathrm{Pb}$ $(1.24 \mathrm{mg} / \mathrm{kg})$ and $\mathrm{Cu}(0.28 \mathrm{mg} / \mathrm{kg}), \mathrm{Cr}(0.1 \mathrm{mg} / \mathrm{kg})$ and $\mathrm{Cd}$ was beyond the limit of detection. Site 4 : $\mathrm{Fe}(35.33 \mathrm{mg} / \mathrm{kg})$ recorded the highest metal concentration in soil, followed by $\mathrm{Cu}$ $(0.31 \mathrm{mg} / \mathrm{kg}), \mathrm{Pb}(0.3 \mathrm{mg} / \mathrm{kg}), \mathrm{Cr}(0.09 \mathrm{mg} / \mathrm{kg})$, and $\mathrm{Cd}$ was not detected (ND). Site 5: Fe with $(28.43 \mathrm{mg} / \mathrm{kg})$ showed the highest metal concentration in soil, followed by $\mathrm{Pb}$ $(1.03 \mathrm{mg} / \mathrm{kg}), \mathrm{Cu}(0.27 \mathrm{mg} / \mathrm{kg}), \mathrm{Cr}(0.1 \mathrm{mg} / \mathrm{kg})$ and the least was $\mathrm{Cd}$ (ND). Site 6: Indicated that Fe with $(33.31 \mathrm{mg} / \mathrm{kg})$ recorded the highest concentration of metals, followed by $\mathrm{Pb}$ $(1.2 \mathrm{mg} / \mathrm{kg}), \mathrm{Cu}(0.27 \mathrm{mg} / \mathrm{kg}), \mathrm{Cr}(0.01 \mathrm{mg} / \mathrm{kg})$, and $\mathrm{Cd}$ was beyond the detection of limit (Table 3 ). The paired T-test analysis for concentration of $\mathrm{Cr}$, $\mathrm{Fe}$, and $\mathrm{Pb}$ in soil near the two dumpsites show that there were statistically significant differences in concentration levels of $\mathrm{Cr}, \mathrm{Fe}$, and $\mathrm{Pb}$ while $\mathrm{Cu}$ Show no statistically significant difference between the two dumpsites (Table 3 ).

Table 2: Soil $\mathrm{pH}$ and heavy metal concentrations in soil ( $\mathrm{mg} / \mathrm{kg})$ near Jimeta dumpsite

\begin{tabular}{lrrrrrr}
\hline Site & $\mathbf{C r}$ & $\mathbf{F e}$ & $\mathbf{C d}$ & $\mathbf{P b}$ & $\mathbf{C u}$ & $\mathbf{p H}$ \\
\hline 1 & 0.1 & 27.54 & ND & 0.28 & 0.44 & 6.46 \\
2 & 0.1 & 35.68 & ND & 1.19 & 0.13 & 6.54 \\
3 & 0.01 & 33.39 & ND & 1.35 & 0.58 & 6.98 \\
4 & 0.2 & 24.34 & ND & 0.23 & 0.32 & 5.76 \\
5 & 0.2 & 36.22 & ND & 1.2 & 0.14 & 5.99 \\
6 & 0.02 & 31.28 & ND & 1.29 & 0.44 & 6.45 \\
Total & $\mathbf{0 . 6 3}$ & $\mathbf{1 8 8 . 4 5}$ & & $\mathbf{5 . 5 4}$ & $\mathbf{2 . 0 5}$ & $\mathbf{3 8 . 1 8}$ \\
Mean & $\mathbf{0 . 1 1}$ & $\mathbf{3 1 . 4 0}$ & & $\mathbf{0 . 9 2}$ & $\mathbf{0 . 3 4}$ & $\mathbf{6 . 3 6}$ \\
\hline
\end{tabular}

ND $=$ Not Detected 
Table 3: Soil $\mathrm{pH}$ and heavy metal concentrations in soil $(\mathrm{mg} / \mathrm{kg})$ at Ngurore dumpsite

\begin{tabular}{|c|c|c|c|c|c|c|c|}
\hline Site & $\mathrm{Cr}$ & $\mathbf{F e}$ & & $\mathrm{Cd}$ & $\mathbf{P b}$ & $\mathrm{Cu}$ & pH \\
\hline 1 & 0.1 & & 34.48 & ND & 0.22 & 0.31 & 8.32 \\
\hline 2 & 0.1 & & 31.23 & ND & 1.04 & 0.28 & 8.26 \\
\hline 3 & 0.01 & & 29.71 & ND & 1.24 & 0.22 & 8.03 \\
\hline 4 & 0.09 & & 35.33 & ND & 0.3 & 0.31 & 8.12 \\
\hline 5 & 0.1 & & 28.43 & ND & 1.03 & 0.27 & 7.65 \\
\hline 6 & 0.01 & & 33.31 & ND & 1.2 & 0.29 & 8.45 \\
\hline Total & 0.41 & & 192.49 & & 5.03 & 1.68 & 48.83 \\
\hline Mean & 0.06 & & 32.08 & & 0.84 & 0.28 & 8.14 \\
\hline
\end{tabular}

\section{Discussion}

Results obtained in table 2 and 3 show that the $\mathrm{pH}$ values of soil samples at the two dumpsites were slightly alkaline. Ngurore dumpsite had a mean $\mathrm{pH}$ value of 8.14 compared to 6.36 mean soil $\mathrm{pH}$ value obtained at Jimeta site, which was slightly acidic. The soil $\mathrm{pH}$ values obtained in this study were slightly similar to the report of Hunachew and Sandip, (2011), who observed pH values of a disposal site in Addis Ababa area to be slightly basic (pH 8.17 \pm 0.95$)$ in the dumpsite and ( $\mathrm{pH} 7.37 \pm 0.37$ ) in grazing land, but lower than the findings of a similar study in Cameroon (8.559.40) (Adjia et al., 2008). This might be as a result of the sorption of metals in the soil (Lee and Saunders, 2003). Result of $\mathrm{pH}$ values obtained in our study may be attributed to the buffering effect of soil organic matter against $\mathrm{pH}$ changes in addition to the release of basic cation during organic matter decomposition. This result was also supported by Obasi et al. (2012), who stated that the $\mathrm{pH}$ levels that are acidic tend to have an increased micronutrient solubility and mobility as well as increased heavy metal concentration in the soil.

The mean concentration of the exchangeable cation in soil for the Jimeta site was: $\mathrm{Fe}(31.4$ $\mathrm{mg} / \mathrm{kg})>\mathrm{Pb}(0.92 \mathrm{mg} / \mathrm{kg})>\mathrm{Cu}(0.34 \mathrm{mg} / \mathrm{kg})>\mathrm{Cr}$ $(0.11 \mathrm{mg} / \mathrm{kg})>\mathrm{Cd}$ (below limit of detection), while the mean concentration of the heavy metals in soil for Ngurore site was: $\mathrm{Fe}(32 \mathrm{mg} / \mathrm{kg})>\mathrm{Pb}$ $(0.83 \mathrm{mg} / \mathrm{kg})>\mathrm{Cu}(0.28 \mathrm{mg} / \mathrm{kg})>\mathrm{Cr}(0.07 \mathrm{mg} / \mathrm{kg})$ $>\mathrm{Cd}$ (below limit of detection). The concentration of Fe in Ngurore site was higher than that of Jimeta site. However, the concentration of heavy metals at Jimeta dumpsite was higher than that obtained at Ngurore dumpsite indicating that the mean concentration of exchangeable cation is directly related to the capacity of absorption of heavy metals since this depend on the combination of the soil properties and the specific characteristics of the element (Nanven et al., 2015). The results of $\mathrm{Cu}$ from the dumpsites in the present study is low when compared to the report of Nanven et al.
(2015), who showed that the mean concentrations of copper $(\mathrm{Cu})$ in the dumpsite and farm soil samples in KuruJantar were 130.19 and 63.23 $\mathrm{mg} / \mathrm{kg}$, respectively. The concentration of $\mathrm{Cu}$ in this study was lower than the values reported by Adewuyi and Opasina (2010), at Lagos metropolis, Nigeria who carried out an assessment of the physicochemical properties and heavy metal concentration of leachates from Aperin abandoned dumpsite in Lagos City.

The results reported here confirm that the soil obtained nearJimeta and Ngurore dumpsites contained substantial amounts of metals with exception of $\mathrm{Cd}$ which was found to be below the limit of detection by the machine. The concentrations of these metals were found to be within the safe limits prescribed by the $\mathrm{FAO} / \mathrm{WHO}$, except for lead which was above the safe limit. However cultivation of crops on this soilmay lead to accumulation of heavy metals in the plants.

\section{Acknowledgement}

The support received from Mr. Eli Joel and Mr. Yohanna Dauda during collection and analysis of samples is appreciated. Also, the authors wish to thank the Department of Chemistry, Adamawa State University Mubi, for the analysis of soil samples.

\section{References}

Adebayo, A.A. and Tukur, A. L. (1999).Adamawa State in maps.ISBN 978- 35157-0-5.Pp 7.

Adelekan B. A and Alawode A. O. (2011). Contributions of municipal refuse dumps to heavy metals concentrations in soil profile and groundwater in Ibadan Nigeria. Journal of Applied Biosciences, 40:2727-2737.

Abdallah S. A, Uzairu A, Kagbu J. A, Okunola O. J. (2011). Mobility and bioavailability of $\mathrm{Pb}, \mathrm{Cr}, \mathrm{Zn}, \mathrm{Cd}, \mathrm{Mn}$ and $\mathrm{Cu}$ from waste soils of refuse dumpsites in Kano Metropolitan City, Nigeria. Australian Journal of Basic and Applied Sciences, 5 (8):707-715.

Adjia, R., Fezeu, W.M.L., Tchatchueng, J.B., 
Sorho, S., Echevarria, G. and Ngassoum, M.B. (2008). Long term effect of municipal solid waste amendment on soil heavy metal content of sites used for periurban agriculture in Ngaoundere, Cameroon. African Journal of Environmental Science and Technology, 2(12): 412-421.

Adewuyi, G.O. and Opasina, M.A. (2010). Physicochemical and heavy metals assessments of leachates from Aperin abandoned dumpsite in Ibadan City, Nigeria. European Journal of Chemistry, 7(4):1278-1283.

Adriano, D.C. (2003). Trace Elements in Terrestrial Environments: Biogeochemistry, Bioavailability and Risks of Metals, Springer, New York, NY, USA, 2nd edition.

Al Jassir, M. S., Shaker, A. and Khaliq, M.A. (2005).Deposition of heavy metals on green leafy vegetables sold on roadsides of Riyadh city, Saudi-Arabia Bull. Environmental Contamination Toxicology, 75: 1020-1027.

Ali, N., Sardar, K., Said, M., Salma, K., Sadia, A., Sadaf, S., Toqeer, A., and Miklas, S. (2015). Toxicity and bioaccumulation of heavy metals in spinach (Spinaciaoleracea) grown in a controlled environment. International Journal of Environmental Research on Public Health, 12: 7400-7416.

Chailapakul. O., Korsrisakul, S., Siangproh, W., and Grudpan, K. (2007). Fast and simultaneous detection of heavy metals using a simple and reliable microchipelectrochemistry route: An alternative approach to food analysis. Talanta.74: 683689.FAO/WHO,

Codex Alimentarius Commission (2001). Food Additives and Contaminants. Joint FAO/WHO Food Standards programme, ALINORM 01/12A:1-289.

FAO/WHO. (2007). Joint FAO/WHO Food Standard Programme Codex Alimentarius Commission 13th Session. Report of the Thirty Eight Session of the Codex Committee on Food Hygiene. Houston, Texas, USA. ALINORM.

Fytianos, K., Katsianis, G., Triantafyllou, P., and Zachariadis, G. (2001).Accumulation of heavy metals in vegetables grown in an industrial area in relation to soil. Bulletin of Environmental Contamination Toxicology, 67: 423-430.

Gupta, U.C., Subhas, C., and Gupta, M.D. (2008). Selenium in soils and crops, its deficiencies in livestock and humans: Implications for management. Community of Soil Science and Plant Analysis, 29: 1791-1807.

Hunachew, B. and Sandip, B. (2011).Assessment of the Pollution Status of the Solid Waste Disposal Site of Addis Ababa City with
$\mathrm{S}$ o $\mathrm{me} \quad \mathrm{S}$ e 1 e c t e d $\mathrm{T} \mathrm{r}$ a c e Elements.Ethiopianworld Applied Sciences Journal, 14 (7):1048-1057.

Kabata-Pendias, A. and Pendias, H. (2001). Trace Metals in Soils and Plants, CRC Press, Boca Raton, Fla, USA, 2nd edition, 43.

Khan, S., Cao, Q., Zheng, Y.M., Huang, Y.Z. and Zhu, Y.G. (2008).Health risks of heavy metals in contaminated soils and food crops irrigated with waste water in Beijing, China. Environmental Pollution, 52: 686-692.

Kiende, J.I., Kawaka, F., Orinda, G., and Okemo, P. (2012): Assessment of heavy metal concentrations in urban grown vegetables in Thika Town, Kenya. African Journal Food Science, 6: 41-46.

Lee, M.K. and Saunders, J.A. (2003). Effect of pH on metal precipitation and sorption: Field Bioremediation and Geochemical Modeling Approaches. Vadose Zone Journal, 2:177-185.

Maleki, A., and Zarasvand, M.A. (2008).Heavy metals in selected edible vegetables and estimation of their daily intake in Sanandaj, Iran. The Southeast Asian Journal of Tropical Medicine and Public Health, 39 (2):335-340.

Marshall, F. (2004). Enhancing food chain integrity: quality assurance mechanism for air pollution impacts on fruits and vegetables systems. Crop Post Harvest Program, Final Technical Report (R7530). http://www.sussex.ac.uk/spru/1-4-7-1-111.html.

McLaughlin, M.J., Zarcinas, B. A., Stevens, D. P. and Cook, N. (2000) "Soil testing for heavy metals," Communications in Soil Science and Plant Analysis, 31 11-14, 1661-1700.

Nanven, N. D., Egila, J. N. and Lohdip, Y. N. (2015). Heavy Metal Concentrations in Some Vegetables Grown in a Farm Treated with Urban Solid Waste in KuruJantar, Nigeria British Journal of Applied Science and Technology, 8(2): 139-147.

Nikolić, N., Borišev, M., Pajević, S., Arsenov, D., and Župunski, M. (2014).Comparative assessment of mineral elements and heavy metals accumulation in vegetable species.Food and Feed Research, 41: $115-123$.

Obasi N. A, Akubugwo E. I, Ugbogu OC, Otuchristian G.(2012). Assessment of physicochemical properties and heavy metals bioavailability in dumpsites along Enuguport Harcourt Expressways, Southeast, Nigeria.Asian Journal of Applied Sciences, 5(6):342-356.

Olarinoye I. O, Sharifat I, Kolo M. T. (2010). Heavy metal content of soil samples from two major dumpsites in Minna. Natural and 
Applied Science Journal, 11(1):90-102.

Oluyemi E. A, Feuyit G, Oyekunle J. A. O, Ogunfowokan A. O. (2008). Seasonal variations in heavy metal concentrations in soil and some selected crops at a landfill in Nigeria. African Journal of Environmental Science and Technology, 2(5): 89-96.

Radwan M.A and A. K. Salama, (2006) "Market basket survey for some heavy metals in Egyptian fruits and vegetables," Food and Chemical Toxicology, 44:8-11.

Sharma, R.K., Agrawal, M., and Marshall, F.M., (2006). Heavy metals contamination in vegetables grown in wastewater irrigated area of Varanasi, India. Bulletin of Environment Contamination and Toxicology, 77:311-318.

Sharma, R.K., Agrawal, M., and Marshall, F.M. (2008a). Heavy metals $(\mathrm{Cu}, \mathrm{Cd}, \mathrm{Zn}$ and $\mathrm{Pb})$ contamination of vegetables in Urban India: a case Study in Varanasi. Environmental
Pollution, 154:254-263.

Sharma, R.K., Agrawal, M., Marshall, F.M. (2008b).Atmospheric depositions of heavy metals $(\mathrm{Cd}, \mathrm{Pb}, \mathrm{Zn}$, and $\mathrm{Cu})$ in Varanasi city, India.Environmental Monitoring and Assessment, 142 (13):269-278.

Wong, C.S.C., Li, X.D., Zhang, G., Qi, S.H., and Peng, X.Z. (2003).Atmospheric depositions of heavy metals in the Pearl River Delta, China. Atmospheric Environment, 37:767-776.

Wuana R.A., and Okieimen, F.E. (2011) "Heavy metals in contaminated soils: A review of sources, chemistry, risks and best available strategies for remediation, "International Scholarly Research Network, p. 20.

Zhao, Q. and Kaluarachchi, J. J. (2002) "Risk assessment at hazardous wastecontaminated sites with variability of population characteristics," Environment International, 28: 1-2, 41-53. 